\title{
Pengaruh Intensitas Melihat Iklan di Instagram terhadap Pengetahuan dan Perilaku Konsumtif Remaja Putri
}

\author{
Nia Sapma Apriliana ${ }^{1}$ \\ Magister Ilmu Komunikasi, Universitas Diponegoro, Semarang, Indonesia \\ nia.sapma@gmail.com \\ Endhar Priyo Utomo \\ Magister Ilmu Komunikasi, Universitas Diponegoro, Semarang, Indonesia \\ endhar.priyo@gmail.com
}

\begin{abstract}
This research aims to know the influence of the intensity of seeing ads selling cosmetics on instagram against level of knowledge and behavior of consumerist cosmetics young women. The population used in this research are students of SMKN 4 Yogyakarta aged 15 to 18 years old. This research method using Quantitative research methods of empirical research methods by means of Surveys using a questionnaire to respondents. The number of samples from this research is as much as 68 students from 212 class 2 and class 3 Department of Hairstyling and Hairstyling Skin SMKN 4 Yogyakarta.And the relevant theory used in this research is the theory of the $S-R$ and Theory AIDDA. The results of this research to prove that there was significant influence between the intensity of seeing ads selling cosmetics on instagram with the level of knowledge and behavior of consumerist cosmetics young women have done the sums between tcalculate the influence of $X$ against the $Y_{1}$ and $Y_{2} X$ against influence, namely $(4.899+2,559) / 2=3.724$ and summation of the $p$ value $(+0.000$ o,013) $/ 2=0.006$. Thus the $t$ value obtained synchronously $(F)$ of 3.724 and $p$ 0.006. With the p of 0.0006 o.o5 then it means there are < significant influence between the intensity of seeing ads selling cosmetics on instagram with the level of knowledge and behavior of consumerist cosmetics young women.
\end{abstract}

Keywords: advertising, consumer knowledge, consumer behavior Instagram, social media

\footnotetext{
${ }^{1}$ Penulis Korespondensi
} 


\begin{abstract}
Abstrak. Penelitian ini bertujuan untuk mengetahui pengaruh intensitas melihat iklan penjualan kosmetik pada instagram terhadap tingkat pengetahuan dan perilaku konsumen kosmetik wanita muda. Populasi yang digunakan dalam penelitian ini adalah siswa SMKN 4 Yogyakarta berusia 15 hingga 18 tahun. Metode penelitian ini menggunakan metode penelitian kuantitatif dengan metode penelitian empiris dengan cara Survei menggunakan kuesioner kepada responden. Jumlah sampel dari penelitian ini adalah sebanyak 68 siswa dari 212 siswa kelas 2 dan kelas 3 Jurusan Tata Kecantikan Rambut dan Tata Kecantikan Rambut SMKN 4 Yogyakarta. Dan teori yang digunakan dalam penelitian ini adalah teori $\mathrm{S}-\mathrm{R}$ dan Teori AIDDA. Hasil penelitian ini membuktikan bahwa ada pengaruh yang signifikan antara intensitas melihat iklan penjualan kosmetik pada instagram dengan tingkat pengetahuan dan perilaku kosmetik konsumeris wanita muda telah melakukan penjumlahan antara thitung pengaruh X terhadap Y1 dan Y2, yaitu $(4,899+2,559) / 2=$ 3,724 dan penjumlahan dari nilai $\mathrm{p}(+0,0000,013) / 2=0,006$. Dengan demikian nilai $t$ diperoleh secara sinkron (F) sebesar 3,724 dan p 0,006. Dengan p sebesar 0,0006, 0,05 maka ada pengaruh yang signifikan antara intensitas melihat iklan penjualan kosmetik pada instagram dengan tingkat pengetahuan dan perilaku kosmetika konsumen kosmetik wanita muda.
\end{abstract}

Kata kunci: iklan, Instagram, media sosial, pengetahuan konsumen, perilaku konsumen

\section{Pendahuluan}

Dalam beberapa dasawarsa terakhir ini, teknologi komunikasi dan informasi telah berkembang. Salah satu bentuk perkembangan tersebut adalah internet. saat ini, internet sangat diminati masyarakat. Dalam beberapa bidang, internet bahkan telah menjadi alat komunikasi utama bagi sebagian besar masyarakat. Dengan adanya internet, masyarakat dapat saling terhubung satu dengan lainnya tanpa dibatasi ruang dan waktu.

Salah satu bentuk perkembangan internet sebagai alat komunikasi adalah hadirnya media sosial. Hadirnya media sosial sedikit banyak memberikan pengaruh dalam berbagai aspek kehidupan. Salah satunya dalam bidang bisnis. Para pelaku bisnis saat ini telah banyak yang menggunakan media sosial sebagai media promosi untuk produk yang dijualnya. Alasan utama para pelaku bisnis menggunakan media sosial sebagai media promosi adalah adanya fakta semakin tingginya tingkat pengguna media sosial dari waktu ke waktu.
Penelitian yang dilakukan We Are Sosial dan Hootsuite terungkap bahwa masyarakat Indonesia merupakan pengguna aktif berbagai media sosial yang ada saat ini, seperti Facebook, Twitter ataupun Instagram. Data We Are Social dan Hootsuite mencatat bahwa lebih dari 130 juta orang Indonesia adalah pengguna aktif di media sosial dan rata-rata menghabiskan waktu 3 jam lebih untuk mengakses media sosial. We Are Social dan Hootsuite juga mengungkapkan media sosial yang diminati masyarakat Indonesia adalah YouTube 43\%, Facebook 41\%, WhatsApp 40\%, Instagram 38\%, Line 33\%, BBM 28\%, Twitter 27\%, Google+ 25\%, FB Messenger 24\%, LinkedIn 16\%, Skype 15\%, dan WeChat 14\% (Haryanto, 2018).

Dalam data lain yang dikeluarkan oleh Asosiasi Penyelenggara Jasa Internet Indonesia pada 2016, diketahui bahwa sebagian besar pengguna media sosial atau tepatnya sebanyak $62 \%$ memanfaatkan media sosial untuk melakukan transaksi bisnis online (Hidayat, 2016). 


\begin{abstract}
Melihat fakta di atas, para pelaku bisnis menjadi terdorong untuk menggunakan media sosial sebagai "alat" untuk mengenalkan produk atau jasa yang dijualnya dalam bentuk iklan yang ditayangkan di media sosial yang ada saat ini. Para pelaku bisnis mengiklankan produk dan jasanya di media sosial dengan intensitas waktu tertentu dengan harapan produk atau jasa yang ditawarkan dapat dikenal luas oleh pelanggannya. Salah satu media sosial yang digunakan untuk mengiklankan produk atau jasa yang ditawarkan adalah instagram.
\end{abstract}

Dalam beberapa penelitian terdahulu, disebutkan bahwa terdapat pengaruh antara intensitas seorang pelanggan dalam melihat iklan di media sosial terhadap tingkat pengetahuan dan perilaku konsumtif pelanggan untuk membeli produk yang ditawarkan. Penelitian terhadap siswa siswi di salah satu Sekolah Menengah Pertama di Tangerang Selatan menyebutkan bahwa terdapat pengaruh yang sangat signifikan antara para pelanggan online shop di media sosial terhadap perilaku konsumtif siswa siswi tersebut (Islamy, 2015). Penelitian lainnya dengan berjudul "Pengaruh Digital Marketing Lazada Indonesia terhadap Brand Awareness dan Minat Beli Konsumen" menemukan bahwa terdapat pengaruh yang positif antara pemasaran yang dilakukan secara digital (digital marketing) terhadap minat beli konsumen dan brand awareness dari para respondennya (Fauziah, 2015). Penelitian yang dilakukan oleh Umi Hidayatun menemukan bahwa terdapat pengaruh positif intensitas penggunaan media sosial terhadap perilaku konsumtif dari remaja (Hidayatun, 2015) .

Dari beberapa penelitian yang telah dilakukan sebelumnya sebagaimana yang telah dijelaskan di atas, dapat diketahui bahwa terdapat pengaruh yang sangat signifikan antara tingkat intensitas seseorang mengakses sebuah iklan di media sosial dengan tingkat pengetahuan pelanggan terhadap suatu produk yang ditawarkan. Iklan media sosial juga berpengaruh terhadap perilaku konsumtif terhadap produk yang ditawarkan tersebut.

Dalam penelitian ini, dijelaskan bahwa yang dimaksud dengan intensitas atau terpaan media adalah kegiatan mendengar, melihat, membaca pesan yang dilakukan oleh individu terhadap suatu media. Intensitas melihat media adalah berusaha mencari data khalayak tentang penggunaan media yang dalam penelitian ini meliputi frekuensi ataupun durasi penggunaan. Frekuensi mengenai seberapa sering masyarakat terkena terpaan iklan, sedangkan durasi mengenai seberapa lama masyarakat terkena terpaan iklan. Asumsinya, semakin lama dan semakin sering seseorang terkena terpaan iklan di media maka kemungkinan seseorang untuk mendapatkan pengaruh dari iklan akan semakin jelas (Islamy, 2015). Selain frekuensi dan durasi melihat iklan, kemungkinan seseorang mendapatkan pengaruh dari iklan adalah timbulnya perhatian atau atensi terhadap media, yang penelitian ini adalah instagram. Atensi adalah perhatian atau cara manusia yang dilakukan secara aktif untuk memproses sejumlah informasi yang disediakan oleh indera, memori yang tersimpan, dan oleh proses-proses kognitif lain

Pengaruh iklan terhadap perilaku konsumen selain dilihat dari segi dampak ekonomi, iklan juga memunculkan dampak psikologi komunikasi untuk laki-laki ataupun perempuan meliputi aspek afektif, kognitif, dan konatif baik secara sendiri maupun bersama-sama. Pengaruh psikologi komunikasi yang berada dalam wilayah kognitif dapat menumbuhkan perhatian khalayak terhadap sesuatu secara lebih 
tinggi dibanding yang lain. Perhatian tersebut akan mengarah pada bertambahnya pengetahuan konsumen tentang produk yang ditawarkan. Selain aspek kognitif, iklan memberikan dampat psikologis pada aspek afektif. Pengaruh pada aspek ini dapat dilihat dalam perilaku seseorang di tengah masyarakat. Karena pengaruh iklan, pada akhirnya, masyarakat membentuk perilaku tertentu, antara lain merasa lebih nyaman dan terasa lebih percaya diri dengan menggunakan produk tertentu (tentu saja yang telah diiklankan). Ini berarti bahwa aspek afektif ini terjadi ketika seseorang telah mengambil tindakan dari apa yang dilihatnya. Selanjutnya, masuk pada aspek konatif. Konatif adalah tahap dimana iklan sudah membuat seseorang menerapkan barang dan jasa secara berlebihan seperti berbelanja barang yang diiklankan jauh diatas yang dibutuhkannya. Pada aspek inilah, muncul perilaku konsumtif seseorang (Widyatama, 2009).

Pengaruh intensitas melihat iklan akan berpengaruh pada tingkat pengetahuan seseorang terhadap barang atau jasa yang diiklankan. Bahkan, intensitas melihat iklan dapat berdampak pada munculnya perilaku konsumtif, yaitu pemborosan pembelian barang yang dilakukan akibat keinginan untuk menjadi seperti apa yang diiklankan. Shalahudin (Ali, 2009) mengatakan bahwa pengetahuan atau tingkat intelegensi adalah kemampuan untuk meletakkan hubungan dari proses berpikir. Sementara itu, Jean Piaget (Ali, 2009) mendefinisikan tingkat pengetahuan adalah akal budi berdasarkan aspek kognitifnya. Tingkat pengetahuan akan berpengaruh pada perubahan perilaku. Ini berarti bahwa semakin banyak pengetahuan yang didapatkan maka semakin besar pula potensi perilaku berubah sesuai dengan ilmu tersebut.
Dari apa yang telah diuraikan di atas, dapat diambil hipotesa penelitian sebagai berikut.

a. Terdapat pengaruh antara intensitas melihat iklan (X) dengan tingkat pengetahuan (Y1)

b. Terdapat pengaruh antara intensitas melihat iklan (X) dengan perilaku konsumtif (Y2)

c. Terdapat pengaruh antara intensitas melihat iklan (X) dengan tingkat pengetahuan (Y1) dan perilaku konsumtif (Y2) kosmetik remaja putri.

\section{Metode Penelitian}

Dalam penelitian ini penulis menggunakan paradigma positivistik. Positivistik atau positivisme memiliki pengaruh yang amat kuat terhadap disiplin ilmu. Metode penelitian kuantitatif bersifat deduktif karena penelitian dilakukan dari umum ke khusus untuk menjawab rumusan masalah digunakan konsep atau teori sehingga dapat dirumuskan hipotesis. Hipotesis yang telah dirumuskan kemudian diuji melalui pengumpulan data lapangan.

Jenis penelitian yang digunakan pada penelitian ini adalah jenis penelitian eksplanasi survei. Jenis eksplanasi dimaksudkan untuk menjelaskan suatu sampel terhadap populasinya atau pengaruh satu variabel dengan variabel lain. Pada format eksplanasi survei, peneliti membangun hipotesis penelitian dan mengujinya di lapangan karena format penelitian ini bertujuan untuk mencari hubungan sebab-akibat dari variabelvariabel yang diteliti

Dalam penelitian ini, populasi dari objek penelitian adalah seluruh remaja putri yang merupakan siswi SMKN 4 Yogjakarta, yaitu sebanyak 212 orang. Sebagaimana diketahui bahwa, SMKN 4 Yogjakarta memiliki 2 (dua) pilihan 
jurusan, yaitu Jurusan Tata Kecantikan Kulit dan Jurusan Tata Kecantikan Rambut. Pemilihan populasi ini atas dasar asumsi bahwa siswa yang bersekolah di tempat tersebut memiliki tingkat pengetahuan dan tingkat kebutuhan yang tinggi terhadap produk kosmetik yang menjadi objek produk dari penelitian ini.

Untuk mendapatkan hasil yang signifikan, penulis mengambil sample dari populasi yang ada yang sekiranya bisa mewakili sebagai responden dari penelitian ini. Teknik sampling yang digunakan adalah Purposive Sampling, yaitu teknik sampling yang memungkin penulis untuk mengambil sample sesuai dengan apa yang dibutuhkan dalam penelitian ini. Teknik ini digunakan pada penelitian yang mengutamakan tujuan penelitian daripada sifat populasi dalam menentuan sampel penelitian (Bungin, 2005)

\section{Hasil dan Pembahasan}

\section{Intensitas Melihat Iklan Jual Beli Kosmetik di Instagram}

Hasil penelitian menunjukkan bahwa responden dengan skor pada variabel intensitas melihat iklan kosmetik di Instagram berada dalam kategori tinggi dan sedang dengan frekuensi masingmasing sebanyak 20 orang (29,41\%), yang mempunyai skor kategori sangat tinggi ada 8 orang (11,76\%), kategori rendah ada 16 orang $(23,53 \%)$ dan yang mempunyai kategori sangat rendah ada 4 orang (5,88\%). Jika dirata-rata, intensitas melihat iklan kosmetik di Instagram pada siswa SMKN 4 masuk dalam kategori baik. Ini karena siswa yang mengambil jurusan tata kecantikan kulit dan rambut, membuat mereka mau tidak mau harus mengerti tentang berbagai jenis dan harga kosmetik rambut dan kosmetik kulit yang ada. Kegiatan mencari informasi tentang kosmetik selain digunakan untuk penge- tahuan pribadi, juga untuk pengetahuan yang mendukung keahliannya dalam belajar di sekolah. Instagram merupakan salah satu media sosial yang sedang digandrungi kalangan muda termasuk siswi SMK 4 Yogyakarta sehingga melalui instagram inilah mereka sering mengakses pengetahuan tentang kosmetik.

\section{Tingkat Pengetahuan}

Hasil penelitian pada variable tingkat pengetahuan tentang kosmetik di Instagaram menunjukkan pada kategori baik. Dari hasil penelitian, terdapat 36 orang $(52,94 \%)$, sangat baik ada 17 orang (25,00\%), cukup baik 13 orang $(19,12)$ dan masuk kategori buruk ada 2 orang $(2,94 \%)$. Tidak ada responden yang skornya masuk dalam kategori sangat buruk.

Berdasarkan data tersebut, dapat disimpulkan bahwa tingkat pengetahuan tentang iklan kosmetik siswi SMKN 4 Yogyakarta berada dalam kategori baik. Akibat tingkat intensitas melihat iklan kosmetik di Instagram yang dapat dibilang sering, maka pengetahuannya baik. Mereka menyadari bahwa pengetahuan tentang jenis dan harga kosmetik merupakan hal yang penting untuk menunjang pengetahuannya dalam belajar tata kecantikan. Oleh karena itu, sebagaian besar dari mereka sering melihat informasi seputar kosmetik di internet, salah satunya di media sosial Instagram.

\section{Perilaku Konsumtif Kosmetik Remaja Putri}

Hasil penelitian menunjukkan bahwa skor responden pada variabel perilaku konsumtif masuk dalam kategori tidak konsumtif ada 23 orang $(33,82 \%)$, cukup konsumtif ada 20 orang (29,41\%), sangat tidak konsumtif ada 18 orang $(26,47 \%)$, baik ada 4 orang $(5,88 \%)$, sangat 
konsumtif 3 orang $(4,41)$. Hal ini membuktikan bahwa hanya beberapa siswi yang mampu berbelanja kosmetik, dan itupun dalam batas yang wajar atau hanya untuk kepentingan praktik sehingga perilaku konsumtif didasari oleh kemampuan membeli dan kebutuhan pribadi serta kebutuhan sekolah saja. Artinya bahwa sifat konsumtifnya buruk.

\section{Tabulasi Silang}

Pada uji tabulasi silang antar variabel dapat diketahui persilangan antara intensitas melihat iklan dengan tingkat pengetahuan tentang kosmetik. Jumlah paling besar ada pada kolom intensitas melihat iklan tinggi dan pengetahuan tentang kosmetik baik, yaitu 15 orang atau $75 \%$ dari seluruh intensitas melihat iklan tinggi. Ini berarti bahwa dari 20 orang yang mempunyai intensitas melihat iklan kosmetik tinggi, terdapat 15 orang (75\%) yang mempunyai pengetahuan tentang kosmetik baik. Ini menunjukkan bahwa semakin tinggi intensitas melihat iklan kosmetik dari siswi SMKN 4 Yogyakarta, maka akan meningkatkan tingkat pengetahuan tentang kosmetik siswi SMKN 4 Yogyakarta tentang kosmetik. Hasil uji korelasi mendukung tabulasi silang yang ada, hubungan antara variabel Intensitas melihat iklan kosmetik dengan tingkat pengetahuan kosmetik menunjukkan angka $r$ hitung sebesar 0,516 dan tingkat signifikansi $0,000<0,05$, yang artinya hubungan antara Intensitas melihat iklan kosmetik dengan tingkat pengetahuan kosmetik adalah berkorelasi sedang dan signifikan.

Hal di atas membuktikan bahwa tingkat pengetahuan seseorang terhadap apapun dipengaruhi informasi yang dia terima. Istilah pengetahuan mernurut Chaplin (dalam Ali, Asrori, 2008: 26) diartikan sebagai Proses kognitif, proses berpikir, daya menghubungkan, kemam- puan menilai, dan mempertimbangkan. Informasi menjadi penting untuk pengetahuan. Ini juga sesuai dengan teori S-R Theory yang mengatakan bahwa proses belajar merupakan suatu tanggapan dari seseorang terhadap suatu rangsangan yang diberikan (Dharmesta dan Handoko, 2008: 34).

Tabulasi silang antara intensitas melihat iklan dengan perilaku konsumtif kosmetik menunjukkan bahwa jumlah paling besar ada pada kolom intensitas melihat iklan sedang dan perilaku konsumtif kosmetik sangat tidak konsumtif, yaitu 10 orang atau $50 \%$ dari seluruh intensitas melihat iklan sedang. Ini berarti dari 20 orang yang mempunyai intensitas melihat iklan kosmetik sedang, terdapat 10 orang (50\%) yang mempunyai perilaku konsumtif kosmetik sangat tidak konsumtif. Artinya, ada hubungan yang bertolak belakang, dari penelitian ini dapat disimpulkan bahwa semakin baik intensitas melihat iklan kosmetik siswi SMK 4 Yogyakarta mempunyai kecenderu-ngan prilaku konsumtif yang semakin buruk atau semakin tidak konsumtif. Ini dapat membuktikan bahwa intensitas melihat iklan yang sering belum tentu akan mengakibatkan perilaku konsumtif naik atau tinggi karena untuk menuju perilaku konsumtif harus dilihat faktor-faktor lain seperti kemampuan membeli, tingkat kebutuhan, serta minat yang tinggi. Temuan ini juga didukung oleh hasil dari uji korelasi. Hubungan antara Intensitas melihat iklan kosmetik dengan perilaku konsumtif kosmetik menunjukkan angka $\mathrm{r}$ hitung sebesar 0,300 dan tingkat signifikansi $0,013<0,05$, yang artinya Intensitas melihat iklan kosmetik dengan perilaku konsumtif kosmetik berkorelasi lemah dan signifikan. Artinya, intensitas melihat iklan kosmetik dari siswi SMK 4 Yogyakarta mempunyai hubungan yang lemah dengan perilaku konsumtif kosmetik siwi SMK 4 Yogyakarta. 
Temuan di atas dapat dijelaskan dengan teori Augusty Ferdinand (dalam Hidayat, Elita, Setiaman, 2012: 4) minat beli dapat didefinisikan sebagai minat transaksional, yaitu kecenderungan seseorang untuk membeli produk. Minat diawali dengan informasi produk yang dimiliki, dan biasanya konsumen mendapat informasi tersebut dari iklan yang disampaikan melalui berbagai media. Itensitas mendapat terpaan iklan ini akan merubah perilaku menjadi konsumtif. Namun dalam kasus perilaku konsumtif kosmetik pada siswi SMK 4 Yogyakarta, minat untuk membeli dimungkinkan ada tetapi untuk sampai pada perilaku konsumtif ada pengaruh tetapi kecil. Ini diperkirakan karena kemampuan membeli siswi SMK 4 Yogyakarta relatif kecil yang ditunjukkan dengan uang saku mereka sebagian besar $\leq$ Rp. 10.000,- yaitu sebanyak 37 siswi $(54,4 \%$ ) dan antara Rp. 11.000,- sampai Rp. 30.000,- ada 28 siswi (41,2\%).

\section{Uji Regresi}

Berdasarkan hasil penelitian tentang uji pengaruh (regresi), terdapat pengaruh signifikan intensitas melihat iklan kosmetik di instagram dengan tingkat pengetahuan terhadap produk kosmetik oleh remaja putri. Hal ini dibuktikan dengan nilai t hitung 4,899 dengan signifikansi o,000 yang berarti signifikansi $<0,05$ maka dapat disimpulkan ada pengaruh signifikan intensitas melihat iklan kosmetik terhadap tingkat pengetahuan kosmetik.

Hasil penelitian tersebut dapat menerangkan bagaimana pengaruh iklan terhadap pengetahuan. Iklan sendiri mempunyai banyak tujuan, terutama mempengaruhi konsumen untuk membeli barang atau jasa. Hal ini sesuai dengan pendapat bahwa iklan bertujuan untuk meningkatkan reaksi calon pembeli atau pembeli potensial terhadap perusahaan dan penawaran produk perusahaan. Iklan dirancang untuk meningkatkan penjualan produk dan keuntungan perusahaan. (Sangadji, Sopiah, 2013: 225). Untuk mencapai tujuan tersebut, iklan dirancang sedemikian rupa menarik untuk menarik perhatian. Media yang digunakan juga memegang peranan penting terkait dengan target pasar yang dituju.

Intensitas atau terpaan media yang di dalamnya mengandung iklan adalah kegiatan mendengar, melihat, membaca pesan yang dilakukan oleh individu terhadap suatu media. Intensitas melihat media adalah berusaha mencari data khalayak tentang penggunaan media yang dalam penelitian ini adalah instagram, frekuensi, maupun durasi penggunaan. Frekuensi adalah mengenai seberapa sering masyarakat terkena terpaan iklan, sedangkan durasi adalah mengenai seberapa lama masyarakat terkena terpaan iklan. Asumsinya, semakin lama dan semakin sering seseorang terkena terpaan iklan di media maka kemungkinan seseorang untuk mendapatkan pengaruh dari iklan akan semakin jelas. Selain frekuensi dan durasi melihat iklan di media, yang membuat kemungkinan seseorang mendapatkan pengaruh dari iklan adalah timbulnya perhatian atau atensi terhadap media dalam hal ini adalah instagram. Iklan akan menimbulkan kepedulian atau atensi terhadap produk dalam iklan sehingga orang yang terkena iklan anak mengingat informasi yang ada. Di sini, indikator-indikator intensitas akan masuk menjadi pengetahuan karena iklan pada dasarnya adalah penyampai pesan/informasi.

Tingkat pengetahuan seseorang terhadap apapun dipengaruhi informasi yang dia terima. Istilah pengetahuan menurut Chaplin (dalam Ali, Asrori, 2008: 26) diartikan sebagai proses kognitif, 
proses berpikir, daya menghubungkan, kemampuan menilai, dan mempertimbangkan. Informasi menjadi penting untuk pengetahuan. Oleh karena itu, dalam dunia periklanan, informasi disampaikan kepada masyarakat untuk mengetahui bahwa ada produk yang seperti ini. Kemudian, pengetahuan akan berpengaruh pada perubahan perilaku. Artinya, semakin banyak informasi yang diketahui maka semakin besar pula potensi perilaku berubah sesuai dengan informasi tersebut. Dalam kepribadian calon konsumen, pengetahuan konsumen diartikan sebagai unsur-unsur yang mengisi akal dan alam jiwa seorang manusia yang sadar di otaknya. Ini akan menimbulkan suatu gambaran, pengamatan (persepsi), konsep dan fantasi terhadap segala hal yang diterima melalui pancainderanya sehingga dapat berpengaruh pada perubahan perilaku konsumen (Dharmmesta dan Handoko, 2008: 89). Temuan sesuai dengan teori S-R Theory yang mengatakan bahwa proses belajar merupakan suatu tanggapan dari seseorang terhadap suatu rangsangan yang diberikan. Teori ini banyak digunakan dalam bidang periklanan, alasannya karena bila perusahaan ingin memperoleh respon dari calon konsumen tentang produknya, maka perusahaan harus mengadakan periklanan secara terus-menerus. Ini karena ketika iklan sering muncul maka diharapkan produk yang diiklankan mudah diingat oleh calon pembeli. (Dharmesta dan Handoko, 2008: 34). Kemajuan teknologi dan trend media sosial yang berkembang pesat memungkinkan produk dipasarkan melalui jaring media sosial seperti facebook dan instragram. Hal ini diperkuat bahwa pasar produk remaja seperti kosmetik lebih pada para remaja, yang sebagian besar mereka aktif di media sosial.
Hasil penelitian ini juga membuktikan bahwa terdapat pengaruh yang signifikan antara intensitas melihat iklan kosmetik terhadap perilaku konsumtif kosmetik. Dapat dilihat dari nilai t hitung 2,559 dengan signifikansi o,013. Nilai signifikansi dihitung adalah < 0,05 maka artinya terdapat pengaruh signifikan intensitas melihat iklan kosmetik terhadap perilaku konsumtif kosmetik. Perilaku konsumtif berarti sikap, atau perilaku yang senang membeli barang untuk mendapatkan gengsi di dalam masyarakat. Perilaku konsumtif juga bisa diartikan sebagai gaya hidup yang bermewah-mewahan. Perilaku konsumtif yaitu perilaku boros dengan tolak ukur berbelanja yang berlebihan, yang lebih didahulukan keinginan bukan kebutuhan atau tidak mengatur skala prioritas. Gejala ini bisa dikatakan sebagai gejala konsumtifisme.

Perilaku konsumtif ini disebabkan karena minat. Menurut Augusty Ferdinand (dalam Hidayat, dkk., 2012: 4), minat beli dapat didefinisikan sebagai minat transaksional, yaitu kecenderungan seseorang untuk membeli produk. Tentu saja, minat diawali dengan informasi produk yang dimiliki. Biasanya, konsumen mendapat dari iklan yang disampaikan melalui berbagai media. Intensitas mendapat terpaan iklan ini akan mengubah perilaku menjadi konsumtif. Perilaku pembelian konsumen seringkali diawali dan dipengaruhi oleh banyakannya rangsangan dari luar dirinya, baik berupa rangsangan pemasaran maupun dari lingkungannya. Rangsangan tersebut kemudian diproses dalam diri sesuai dengan karakteristik pribadinya sebelum akhirnya mengambil keputusan pembelian. Karakteristik pribadi konsumen yang dipergunakan untuk memproses rangsangan tersebut sangat komplek, dan salah satunya adalah motivasi konsumen untuk pembeli. 


\section{Perbandingan dengan Penelitian Terdahulu}

Penelitian ini sesuai dengan hasil penelitian yang dilakukan oleh Nidya Nur Fauziah (2015) menunjukkan adanya pengaruh positif antara minat beli konsumen dengan digital marketing. Sesuai dengan penelitian Daniella Putri Islamy (2015) yang menunjukkan adanya pengaruh positif antara online shop di media sosial instagram terhadap perilaku konsumtif remaja. Penelitian ini juga mendukung hasil penelitian Regina C.M. Chita, Lydia David, dan Cicilia Pali pada 2015 di mana terdapat hubungan antara self control terhadap perilaku konsumtif online shop produk fashion mahasiswa. Selain itu, penelitian ini juga menguatkan hasil penelitian yang dilakukan oleh Umi Hidayatun (2015) yang menunjukkan adanya pengaruh yang signifikan antara intensitas penggunaan media sosial terhadap perilaku konsumtif remaja.

Penelitian ini secara serempak juga membuktikan bahwa terdapat pengaruh antara intensitas melihat iklan jual beli kosmetik di Instagram (X) dengan tingkat pengetahuan (Y1) dan perilaku konsumtif (Y2) kosmetik remaja putri. Hal ini dibuktikan dengan $\mathrm{t}$ serempak/Fsebesar 3,724 dan p o,oo6. Hasil penelitian ini mendukung teori strategi komunikasi yang menyatakan komunikator berperan lebih banyak dibandingkan komunikan. Setiap hal yang dilakukan oleh komunikator akan menimbulkan efek bagi komunikan. Para ahli komunikasi melihat bahwa dalam melancarkan proses komunikasi harus dilakukan pendekatan A-A Procedure atau from Attention to Action Procedure. Hal ini merupakan penyederhanaan dari teori yang disingkat AIDDA. AIDDA merupakan sebuat teori singkatan dari : A = Attention atau Perhatian, I = Interest atau Minat, D $=$ Desire atau hasrat, $\mathrm{D}=$ Decision atau Keputusan, A = Action atau Kegiatan. Pada era komunikasi massa dan digital seperti saat ini, komunikator dapat menyampaikan berbagai pesan melalui berbagai media, tidak terkecuali media sosial. Ketika komunikator mampu membangkitkan rasa perhatian komunikan, hal itu merupakan awal yang baik bagi terciptanya komunikasi yang efektif dan menguntungkan. Hal ini dikarenakan ketika rasa perhatian (attention) telah muncul dibenak komunikan, maka hal mudah bagi komunikator untuk menumbuhkan minat (interest), menimbulkan hasrat (desire), dilanjutkan dengan datangnya keputusan (decission)untuk melakukan sebuah kegiatan (action) (Effendy, 2000: 304).

\section{Kesimpulan}

Berdasarkan atas yang telah diuraikan di atas, dapat disimpulkan sebagai berikut. Pertama, terdapat pengaruh antara intensitas melihat iklan jual beli kosmetik di Instagram (X) dengan tingkat pengetahuan (Y1) kosmetik remaja putri. Hal ini dibuktikan dari nilai t hitung 4,899 dengan signifikansi o,ooo. Pengaruh yang ada adalah positif dan signifikan dengan Koefisien Determinasi sebesar $26,7 \%$ yang berarti Intensitas melihat iklan kosmetik mampu menerangkan pengetahuan tentang kosmetik sebesar 26,7\%. Dengan demikian, hipotesis penelitian yang menyatakan terdapat pengaruh antara intensitas melihat iklan jual beli kosmetik di Instagram (X) dengan tingkat pengetahuan (Y1) kosmetik remaja putri diterima. Hal ini sesuai dengan teori S-R Theory yang mengatakan bahwa proses belajar merupakan suatu tanggapan dari seseorang terhadap suatu rangsangan yang diberikan. Bila perusahaan ingin memperoleh respon dari calon konsumen tentang produknya, maka perusahaan harus mengadakan periklanan secara terus-menerus. Sebab ketika iklan sering muncul maka diharapkan produk yang 
diiklankan mudah diingat oleh calon pembeli. Hal ini berarti bahwa intensitas informasi yang diterima dapat mempengaruhi tingkat pengetahuan seseorang terhadap apapun, termasuk terhadap kosmetik.

Kedua, penelitian ini juga menemukan bahwa pengaruh antara intensitas melihat iklan jual beli kosmetik di Instagram (X) dengan perilaku konsumtif (Y2) kosmetik remaja putri. Hal ini dibuktikan dengan nilai t hitung 2,559 dengan signifikansi o,013. Pengaruh yang ada adalah positif dan signifikan dengan Koefisien determinasi sebesar 9\% yang berarti intensitas melihat iklan kosmetik mampu menerangkan perilaku konsumtif kosmetik sebesar 9\%. Dengan demikian, hipotesis penelitian yang menyatakan terdapat pengaruh antara intensitas melihat iklan jual beli kosmetik di Instagram (X) dengan perilaku konsumtif (Y2) kosmetik remaja putri diterima. Secara teoritis, perilaku konsumtif disebabkan oleh karena minat dan minat diawali dengan inforrmasi produk yang dimiliki. Dalam kepribadian calon konsumen, pengetahuan konsumen diartikan sebagai unsur-unsur yang mengisi akal dan alam jiwa seorang manusia yang sadar di otaknya. Hal ini yang akan menimbulkan suatu gambaran, pengamatan (persepsi), konsep dan fantasi terhadap segala hal yang diterima melalui panca inderanya sehingga dapat berpengaruh pada perubahan perilaku konsumen. Hal ini berarti bahwa intensitas informasi yang diterima dapat mempengaruhi perilaku konsumtif calon konsumen.

Ketiga, terdapat pengaruh antara intensitas melihat iklan jual beli kosmetik di Instagram (X) dengan tingkat pengetahuan (Y1) dan perilaku konsumtif (Y2) kosmetik remaja putri. Hal ini dibuktikan dari hasil penjumlahan nilai $t$ sebesar 3,724 dan p o,oo6. Dengan demikian, hipotesis penelitian yang menyatakan terdapat pengaruh antara intensitas melihat iklan jual beli kosmetik di Instagram (X) dengan tingkat pengetahuan (Y1) dan perilaku konsumtif (Y2) kosmetik remaja putri diterima. Hal ini dapat dijelaskan dengan teori yang menyatakan setiap hal yang dilakukan oleh komunikator akan menimbulkan efek bagi komunikan. Pendekatan $A-A$ Procedure atau from Attention to Action Procedure yang merupakan penyederhanaan dari teori AIDDA (Attention, Interest, D = Desire, Decision, Action) sesuai dengan hasil penelitian ini. Ketika komunikator mampu membangkitkan rasa perhatian komunikan maka akan terciptanya komunikasi yang efektif yang membuat rasa perhatian (attention) telah muncul dibenak komunikan, maka akan menumbuhkan minat (interest), menimbulkan hasrat (desire), dilanjutkan dengan datangnya keputusan (decission) untuk melakukan sebuah kegiatan (action) sehingga intensitas melihat iklan (informasi) akan mempengaruhi pengetahuan konsumen dan perilaku konsumen untuk membeli.

Uji statistik penelitian ini menemukan bahwa iklan mempunyai pengaruh penting dalam mendorong perilaku konsumtif. Bagi pelaku bisnis, ini menguntungkan karena dengan begitu dapat terus menggunakan media sosial untuk beriklan. Namun, bagi khalayak, perilaku ini dapat dikatakan merugikan atau kurang bagus karena perilaku konsumtif akan menciptakan pemborosan sebagai akibat ketidakmampuannya dalam mengontrol proses belanja. Untuk itu, diperlukan suatu 'kebijakan' dari para pembeli untuk menggunakan uangnya secara lebih baik. 
Penelitian ini fokus pada pesan iklan di Instagram. Penelitian-penelitian lain kiranya dapat dikembangkan dengan menggunakan fokus media sosial lainnya seperti Facebook ataupun line. Sampling juga dapat diperluas tidak hanya anak- anak SLTA, tapi juga anak-anak remaja dan usia dewasa. Dengan demikian, akan ditemukan hasil-hasil penelitian yang lebih kaya.

\section{Daftar Pustaka}

Ali, M. d. (2009). Psikologi Remaja. Jakarta: Bumi Aksara.

Bungin, B. (2005). Metode Penelitian Kuantitatif. Jakarta: Kencana Prenada Media Group.

Dharmmesta, B.S. dan Handoko, T.H. (2008). Manajemen Pemasaran Analisis Perilaku Konsumen.Yogyakarta : BPFE Yogyakarta

Effendy, Onong Uchjana. (2000). Ilmu, Teori dan Filsafat Komunikasi. Bandung PT. Citra Aditya Bakti

Fauziah, N (2015). "Pengaruh Digital Marketing Lazada Indonesia Terhadap Brand Awareness dan Minat Beli Konsumen”. Skripsi Sarjana, Fakultas Psikologi dan Ilmu Sosial Budaya Universitas Islam Indonesia, Yogyakarta.

Haryanto, A. T. (2018). "130 Juta Orang Indonesia Tercatat Aktif di Medsos". Inet.detik.com (tanggal publikasi berita : 12 Maret 2018). URL : https://inet.detik.com/cyberlife/d3912429/130-juta-orang-indonesiatercatat-aktif-di-medsos, tanggal akses : 11 Juli 2018
Hidayat, A.T; Elita, FM; dan Setiaman, A. (2012). "Hubungan Antar Atribut Produk Dengan Minat Beli Konsumen". eJurnal Mahasiswa Universitas Padjajaran Volume 1.

Hidayat, M. W. (2016). "3 Media Sosial Favorit Pengguna Internet Indonesia". $\quad$ www.liputan6.com (tanggal publikasi berita : 24 Oktober 2016). URL : https://www.liputan6. com/tekno/read/2634027/3-mediasosial-favorit-pengguna-internetindonesia, tanggal akses 17 Desember 2018

Hidayatun, U. (2015). Pengaruh Instesitas Penggunaan Media Sosial dan Dukungan Teman Sebaya Terhadap Perilaku Konsumtif Pada Siswa Kelas XI SMA Muhamadiyah 3 Jogjakarta . Jogjakarta: Fakultas Ilmu Pendidikan Universitas Negeri Jogjakarta.

Islamy, D. P. (2015). Pengaruh Online Shop pada Media Sosial Instagram Terhadap Perilaku Konsumtif Siswa Siswi SMP Islam Cikal Harapan 1 Bumi Serpong Damai Kota Tangerang Selatan. Jakarta: UIN Syarif Hidayatullah.

Widyatama, R. (2009). Pengantar Periklanan . Yogyakarta: Kelompok Penerbit Pinus. 
Jurnal komunikasi, Volume 13, Nomor 2, April 2019, Hal 179-190 